\title{
HUBUNGAN ANTARA DAYA LEDAK OTOT LENGAN DENGAN KEMAMPUAN SMASH BOLA VOLI PADA EKSTRAKURIKULER
}

(Sekolah Menengah Akhir Pasundan Cikalongkulon)

\author{
Wachyu Bakti Bachtiar' ${ }^{1}$, Budiarto ${ }^{2}$, Ervan Kastrena $^{3}$ \\ Pendidikan Jasmani kesehatan dan Rekreasi \\ Fakultas Keguruan dan Ilmu Pendidikan, Universitas Suryakancana \\ wachyubbachtiar@gmail.com, ervankastrena@unsur.ac.id
}

\begin{tabular}{l}
\hline Info Artikel \\
\hline Sejarah Artikel: \\
Diterima Agustus 2019 \\
Disetujui November 2019 \\
Dipublikasikan Desember \\
2019
\end{tabular}

Keyword:

Daya Ledak Otot Lengan,

Volly

Smash

\begin{abstract}
Abstrak
Komponen kondisi fisik daya ledak otot lengan merupakan aspek yang sangat penting bagi atlet untuk menghasilkan kecepatan dan kekuatan saat melakukan pukulan smash. Penelitian ini bertujuan untuk mengetahui hubungan antara daya ledak otot lengan dengan kemampuan smash. Metode penelitian ini menggunakan penelitian deskriptif korelasional dengan desain penelitian yaitu korelasi rxy. Populasi dalam penelitian ini adalah semua siswa yang mengikuti kegiatan ekstrakurikuler bola voli di SMA Pasundan Cikalongkulon, yang berjumlah 30 siswa. Teknik sampling yang digunakan yaitu sampling jenuh Sugiyono (2001). Sampel dalam penelitian ini sebanyak 30 siswa. Instrumen penelitian yang pertama untuk mengukur daya ledak otot lengan menggunakan two hand medicine ball put (Johnson \& Nelson, 1969, dalam Setiawan \& Budiarto, 2017), Analisis data menggunakan SPSS versi 17. Hasil penelitian menunjukkan: Terdapat hubungan daya ledak otot lengan dengan kemampuan smash bolavoli pada siswa ekstrakurikuler SMA Pasundan Cikalongkulon.
\end{abstract}

\section{Abstrack}

The physical condition component of arm muscle explosive power is a very important aspect for athletes to produce speed and strength when making a smash. This study aims to determine the relationship between arm muscle explosive power and smash ability. This research method uses descriptive correlational research with a research design that is rxy correlation. The population in this study were all students who took part in volleyball extracurricular activities at Pasundan Cikalongkulon High School, totaling 30 students. The sampling technique used is Sugiyono saturated sampling (2001). The sample in this study were 30 students. The first research instrument to measure arm muscle explosive power using two hand medicine ball put (Johnson \& Nelson, 1969, in Setiawan \& Budiarto, 2017), data analysis using SPSS version 17. The results showed: There is a relationship between arm muscle explosive power and ability volleyball smash on extracurricular students at Pasundan Cikalongkulon High School. 
(C) 2019 Universitas Suryakancana

$\square$ Alamat korespondensi:

E-mail: Adirahadian@unsur.ac.id
e-ISSN : 2721-7175 (online)

p-ISSN : 2089-2341 (cetak)

\section{PENDAHULUAN}

Perkembangan bolavoli meningkakan secara signifikan hal itu terlihat dengan banyaknya atlet berprestasi dalam cabang olahrah bolavoli ini. Dalam permainan bolavoli untuk mendapatkan prestasi yang gemilang, maka perlu adanya penguasaan tehnik dasar dan kondisi fisik yang baik. Dalam permainan bolavoli ada beberapa macam teknik dasar yaitu: servis, passing, blok dan smash (Ahmadi, 2007:20). Smash merupakan salah satu senjata ampuh yang sering digunakan oleh para atlet bolavoli untuk melakukan sebuah serangan dan memperoleh sebuah nilai.

Apabila seorang atlet ingin mencapai prestasi yang maksimal dalam cabang olahraga bolavoli, maka faktor kondisi fisik secara bersamaan harus ditingkatkan. Ahmadi (2007:64) menjelaskan bahwa bolavoli termasuk jenis olahraga yang banyak mengandalkan fisik, maka kondisi fisik pemain sangat penting dalam menunjang efektivitas permainan. Selain yang disebutkan di atas untuk memperoleh prestasi yang maksimal di perlukan latihan yang intensif, serta disiplin yang tinggi serta tidak boleh terlepas dari prinsip-prinsip dalam latihan sehingga akan tercapai hasil yang maksimal.
Salah cara untuk meningkatkan kemampuan atau keterampilan teknik dasar smash, maka diperlukan kemampuan fisik yang prima disertai dengan latihan yang cukup. Dalam melakukan gerakan smash terutama untuk mencapai hasil yang optimal diperlukan daya ledak lengan yang baik sehingga menghasilkan laju bola yang keras. Hal tersebut dipertegas oleh Ahmadi, (2007:14) kaitannya dalam pelaksanaan smash, daya ledak otot tungkai memiliki peran untuk memberikan tenaga sewaktu lengan memukul bola yang sekeraskerasnya.

Dalam daya ledak otot lengan merupakan kondisi fisik yang tidak dapat dipisahkan dan merupakan penunjang utama gerakan yaitu kekuatan otot dan kecepatan otot untuk mengarahkan tenaga maksimal untuk mengatasi tahanan. Daya ledak otot tungkai merupakan salah satu faktor sangat penting dan harus diperhatikan dalam permainan bolavoli, terutama pada saat melakukan pukulan, sehingga dengan memiliki daya ledak otot lengan yang baik, akan menghasilkan smash yang lebih baik pula. Sebaliknya apabila seorang atlet memiliki daya ledak otot lengan yang lemah, maka dapat menyebabkan pukulan tidak terlalu keras 
sehingga lebih mudah untuk dibendung oleh lawan.

Berdasarkan data hasil survey dan informasi dari guru pendidikan jasmani yang merangkap sebagai pelatih bolavoli ekstrakurikuler bolavoli di SMA Pasundan Cikalongkulon, penulis mencatat data evaluasi atlet yakni masih jarang meraih kemenangan pada saat bertanding dan pada saat berlatih terlihat banyak atlet yang belum mampu melakukan smash dengan baik, pukulan yang dilakukan sering lemah datangnya atau keluar area permainan. Pada saat melakukan atlet sering gagal, karena kurang terarah dan pukulan bola yang dihasilkan sangat lemah. Berdasarkan pengamatan penulis hal itu ada kaitannya dengan daya ledak otot lengan yang dimiliki oleh atlet bolavoli di SMA Pasundan Cikalongkulon yang dapat dikatakan masih lemah.

Berkaitan permasalahan yang telah diuraikan di atas, maka penulis merasa penting untuk melakukan penelitian ini. Dengan diadakannya penelitian ini, dapat memberikan informasi dengan jelas mengenai kepada guru pendidikan jasmani mengenai hubungan atau kontribusi dari daya ledak otot lengan dengan kemampuan smash dalam permainan bolavoli. Jika penelitian ini menunjukan bahwa daya ledak otot lengan memberikan kontribusi dengan kemampuan smash, maka pelatih di SMA Pasundan Cikalongkulon, nantinya bisa membuat suatu program latihan untuk dapat mengembangkan kemampuan daya ledak otot lengan atlet, sehingga dapat meraih prestasi secara maksimal dalam cabang olahraga bolavoli.

Berdasarkan uraian tersebut, maka penulis ingin melakukan penelitian mengenai: Hubungan Daya Ledak Otot Lengan Dengan Kemampuan Smash Bolavoli Pada Siswa Ekstrakurikuler SMA Pasundan Cikalongkulon.

Metode

Metode yang digunakan dalam penelitian ini adalah metode deskiptif. Mengenai pengertian penelitian deskriptif, Arikunto (2010:3) menjelaskan bahwa "Penelitian deskriptif adalah penelitian yang dimaksudkan untuk menyelidiki keadaan, kondisi atau hal lain-lain yang sudah disebutkan, yang hasilnya dipaparkan dalam bentuk laporan penelitian". Desain penelitian yang diterapkan adalah korelasional rxy. Populasi yang digunakan dalam penelitian ini adalah semua siswa yang mengikuti kegiatan ekstrakurikuler bolavoli di SMA Pasundan Cikalongkulon, yang berjumlah 30 siswa. Teknik pengambilan sampel dalam penelitian ini adalah sampling jenuh. Berdasarkan teknik sampling yang digunakan maka sampel dalam penelitian ini adalah semua siswa yang mengikuti kegiatan ekstrakurikuler bolavoli di SMA Pasundan Cikalongkulon, yang berjumlah 30 siswa. 
Instrumen untuk mengukur daya ledak lengan dan gelang bahu pada anak lakilaki atau perempuan yang berusia 12 tahun hingga tingkat mahasiswa, dengan menggunakan tes two hand medicine ball put (Setiawan \& Budiarto, 2017:175). Instrumen kedua yang digunakan dalam penelitian adalah tes sejauh mana kemampuan siswa dalam melakukan smash pada permainan bolavoli. alat ukurnya denngan menggunakan nomor di setiap sisi lapangan sesuai penilaian yang akan di berikan dan mengunakan alat ukur angka. Tes smash dari Nurhasan, dkk (2007:225) dengan reabilitas tes 0,94 dan validitas tes 0,84 batrey test untuk usia 16-18 tahun. Analisis data menggunakan SPSS versi 17.

Hasil

Tes dan pengukuran ini ditujukan kepada siswa yang mengikuti kegiatan ekstrakurikuler bolavoli di SMA Pasundan Cikalongkulon, Setelah melaksanakan tes dan pengukuran daya ledak otot lengan dengan kemampuan smash diperoleh data sebagai berikut:

Menghitung Rata-Rata dan Simpangan Baku

Tabel 1. Hasil Penghitungan Nilai RataRata dan Simpangan Baku

\begin{tabular}{|l|l|l|l|l|l|}
\hline & $\mathrm{N}$ & Mean & $\begin{array}{l}\text { Std. } \\
\text { Deviati } \\
\text { on }\end{array}$ & $\begin{array}{l}\text { Mini } \\
\text { mum }\end{array}$ & $\begin{array}{l}\text { Maxi } \\
\text { mum }\end{array}$ \\
\hline $\begin{array}{l}\text { Daya Ledak } \\
\text { Otot Tungkai } \\
(\mathrm{X})\end{array}$ & 30 & 3.70 & .702 & 3 & 5 \\
\hline
\end{tabular}

\begin{tabular}{|l|l|l|l|l|l|}
\hline $\begin{array}{l}\text { Kemampuan } \\
\text { Smash } \\
(\mathrm{Y})\end{array}$ & 30 & 10.00 & 5.356 & 4 & 25 \\
\hline
\end{tabular}

Berdasarkan Tabel 1 di atas diperoleh nilai rata-rata dari setiap variabel, variabel $\mathrm{X}$ nilai rata-rata sebesar 3.70 dan simpangan baku sebesar .702, Sedangkan variabel Y nilai rata-rata sebesar 10.00 dan simpangan baku sebesar 5.356.

Pengujian Normalitas

Tabel 2. Penghitungan Pengujian Normalitas

\begin{tabular}{|l|l|l|l|}
\hline Variabel & Sig & $\alpha$ & $\begin{array}{l}\text { Kesimpula } \\
\mathrm{n}\end{array}$ \\
\hline $\begin{array}{l}\text { Daya Ledak Otot } \\
\text { Lengan } \\
(\mathrm{X})\end{array}$ & 0.022 & 0,05 & $\begin{array}{l}\text { Data } \\
\text { Normal }\end{array}$ \\
\hline $\begin{array}{l}\text { Kemampuan } \\
\text { Smash } \\
\text { (Y) }\end{array}$ & 0.292 & 0,05 & $\begin{array}{l}\text { Data } \\
\text { Normal }\end{array}$ \\
\hline
\end{tabular}

Berdasarkan Tabel 2 di atas diperoleh nilai sig dari variabel daya ledak otot lengan $(\mathrm{X})$ sebesar $0.022>\alpha 0.05$. Sedangkan variabel kemampuan smash (Y) nilai sig yang diperoleh sebesar 0.292 $>\alpha$ 0.05. Karena semua variabel memperoleh nilai sig lebih besar dari nilai $\alpha 0.05$, maka artinya data berdistribusi normal. Karena semua data berdistribusi normal maka langkah selanjutnya melakukan uji homogenitas data.

Pengujian Homogenitas

Tabel 3. Penghitungan Pengujian Homogenitas

\begin{tabular}{|c|c|c|c|c|}
\hline Variabel & Dk & Sig & $\alpha$ & Kesimpulan \\
\hline $\begin{array}{l}\text { Daya ledak } \\
\text { otot lengan } \\
(\mathrm{X})\end{array}$ & $(30,30)$ & 0.067 & 0,05 & $\begin{array}{l}\text { Data } \\
\text { Homogen }\end{array}$ \\
\hline $\begin{array}{l}\text { Kemampuan } \\
\text { Smash }\end{array}$ & $30,30)$ & 0.044 & 0,05 & $\begin{array}{l}\text { Data } \\
\text { Homogen }\end{array}$ \\
\hline
\end{tabular}




\begin{tabular}{|l|l|l|l|l|}
\hline (Y) & & & & \\
\hline
\end{tabular}

Dari Tabel 3 di atas dapat dilihat bahwa nilai sig pada variabel daya ledak otot lengan $(\mathrm{X})$ sebesar $0.067>\alpha 0,05$, dan nilai sig pada variabel kemampuan smash (Y) sebesar $0.044>\alpha 0,05$. Sehingga dapat artikan bahwa data variabel $\mathrm{X}$ dan Y semua data bervariansi homogen.

Pengujian Hipotesis

Tabel 4. Hasil Penghitungan Korelasi X dengan $\mathrm{Y}$

\begin{tabular}{|l|l|l|l|l|}
\hline Variabel & $\begin{array}{l}\text { r- } \\
\text { hitung }\end{array}$ & r-tabel & $\begin{array}{l}\mathrm{Si} \\
\mathrm{g}\end{array}$ & $\alpha$ \\
\hline X dengan Y & 0.688 & 0,632 & 0.0 & 0.05 \\
& & & 00 & \\
\hline
\end{tabular}

Berdasarkan Tabel 4 diperoleh variabel daya ledak otot lengan dengan kemampuan smash dari output nilai 0.688 $>0.632$ atau

sig sebesar $0.000<\alpha$ 0.05. maka Ho ditolak dan Ha diterima, maka hubungan daya ledak otot lengan dengan smash sangat kuat atau diyatakan signifikan.

\section{Simpulan}

Berdasarkan hasil penelitian dapat disimpulkan bahwa untuk dapat menghasilkan smash yang cepat dan kuat, maka komponen kondisi fisik daya ledak perlu diperhatikan dan dikembangkan.

\section{Daftar Pustaka}

Ahmadi, Nuril. (2007). Panduan

Olahraga Bola Voli. Surakarta:

Era Pustaka Utama.
Arikunto, Suharsimi. (2010). Prosedur Penelitian Suatu pendekatan praktik. Jakarta: PT Rineka Cipta.

Muhamad Syamsul Taufik (2019) Hubungan Tingkat Konsentrasi Dengan Keterampilan Bermain Futsal Unit Kegiatan Mahasiswa Futsal Universitas Suryakancana Gladi: Jurnal Ilmu Keolahragaan Jilid 10 Terbitan 02 Halaman 6878

Muhamad Syamsul Taufik (2014) Hubungan Antara Indeks Massa Tubuh, Fleksibilitas Dan Kecepatan Reaksi Dengan Kelincahan Pada Cabang

Olahraga Futsal Lembaga Universitas Pendidikan Indonesia Nurhasan, cholil Hasanudin. (2007). Modul Tes dan Pengukuran Keolahragaan. Bandung : FPOK.

Setiawan, Edi dan Budiarto. (2017).

Panduan Melaksanakan Tes, Pengukuran Dan Evaluasi Dalam Pendidikan Jasmani dan Olahraga. Cianjur: PENDOR Universitas Suryakancana 